\title{
Opposing Gazes: Racism and xenophobia in South African schools
}

\author{
Saloshna Vandeyar \\ Department of Humanities Education, Faculty of Education, University of Pretoria, South Africa
}

\section{Thirusellvan Vandeyar}

Department of Science, Math and Technology Education, Faculty of Education, University of Pretoria, South Africa

\begin{abstract}
Utilising a qualitative case study approach, this research study set out to understand discrimination experienced by immigrant students in their interactions with South African students and the prejudice immigrant students expressed against Black South African students. Findings reveal that the discrimination experienced by immigrant students could be clustered into four broad themes namely, categorisations and prototypes, practiced stereotypes; academic and social exclusion and work ethic. Furthermore, statements immigrant students make about South African students seem to fall into two broad categories namely, lack of value for moral integrity and lack of value for education. Educating students to value human dignity and to view each other as cosmopolitan citizens of the world could be a way to ensure social cohesion and harmony of future generations to come.
\end{abstract}

Keywords: immigrant students; racism; social dominance theory; social identity theory; xenophobia 


\section{Introduction}

An immigrant student from Congo who came here with his parents when he was five years old, at the age of 16 is doing very well in a South African school. Like a number of other immigrant students he is favoured by the teacher because he shows consistent eagerness to learn and his homework is always done on time. Outside of the classroom South African Black students call him 'Makwerekwere' which is a negative slang word for foreigners. He shrugs his shoulders thinking 'you lazy bunch, you don't even know how to value education, go on drink and smoke as you do. When I finish school I will get a job and you will not'.

This imagined situation is not atypical to what we found in a research project on immigrant student ${ }^{1}$ identities in South African schools. The challenge we want to address in this paper is to make an inventory of two forms of prejudice and discrimination. One, discrimination experienced by immigrant students in their interactions with South African students ${ }^{2}$ and the prejudice immigrant students express against Black South African students. How to interpret this? Are these forms of racism? Are these forms of xenophobia? How do the experiences of immigrant students relate to a history of apartheid and a current situation where there is formal political and legal democracy but inequalities along racial lines continue to be expressed in education?

First we will sketch a background of South African racism and its legacy. Then we will look at current literature, on xenophobia and racism. We will use that as a framework against which to interpret data we collected in interviews with immigrant students in South Africa. There is no doubt that there are tensions in South Africa between South African and immigrant students. Some of which has been expressed in violence against immigrants (Vandeyar, 2010; Vandeyar, 2011; Vandeyar, 2012; Vandeyar, 2013; Vandeyar \& Vandeyar, 2012). There is controversy about whether that was xenophobia or racism (Hassim, Kupe \& Worby, 2008) or neither of that or just competition. In contributing to identifying what the problem is about we will create a better situation for finding solutions.

\footnotetext{
${ }^{1}$ Immigrant students refer to African students who come from African countries and who are natives of any of

${ }^{2}$ South African students: the terms Coloured, White, Indian and African derive from the apartheid racial classifications of the different peoples of South Africa. The use of these terms, although problematic, has continued through the post-apartheid era in the country. In the context of this paper, South African students refer to the group of people who are of African ancestry and who are classified 'black' in colour, and to fourth or fifth generation Indian students who were born in South Africa.
} 


\section{Racism and Xenophobia in South Africa}

What is the difference between racism and xenophobia?

According to Wallace (1999: 5) xenophobia is a reaction against foreigners (however these may be defined), while racism is a reaction against a generic group (however defined). Xenophobia and racism can thus be seen as an attitude or a mind-set (Harris, 2002). In the South African context however, xenophobia is not just restricted to an attitude or mind set, it has resulted in intense tension between indigenous people and foreigners which in turn has resulted in violent attacks against foreigners (Tshitereke, 1999:4; Krochmal, 2001; Harris, 2002; Hassim, Kupe \& Worby 2008).

\section{Categorising race in South Africa}

Racism is "discrimination or prejudice based on race"; "a belief that race is the primary determinant of human traits and capacities" (Webster's dictionary). Racial differences produce an inherent superiority of a particular race. Early scholarly work in the area of race essentially identified the concept of race as a 'biological fact', with a common understanding drawing upon differences of skin colour and physical attributes, which were then used to explain cultural differences, including language, nationality, and religion (Gilroy, 2000; Ramon, 2000; Essed, 2002). Race categories were used to justify the exploitation of one group by another, based on racial heritage. Social interpretations of race regard the common categorizations of people into different races as more socially and culturally constructed than based upon biology. Even though race does not have a biological meaning, it does have a social meaning which has been legally constructed (Miles, 1982; Gilroy, 1998; Essed, 2002)

"Race" is a social construction invented by people. It is first and foremost a discursive category, "the organizing category of those ways of speaking, systems of representation and social practices (discourses) which utilize a loose, often unspecified set of differences in physical characteristics--skin color, hair texture, physical and bodily features, and so forth--as symbolic markers in order to differentiate one group socially from another (Hall, 1992: 298).

Racism during the apartheid era in South Africa was expressed both as biological and social constructs. The architects of apartheid used differences not only of skin pigmentocracy and physical attributes but also of language, nationality, and religion to socially construct a society based on apartheid ideology. The early years of democracy in South Africa were characterised by a sense of euphoria as the ideals contained in the Constitution provided all citizens with equal opportunities. In everyday and institutional life however, race categories 
continue to operate as also expressed in continued experiences of racism (Essed, 2002). But today a new middle class has emerged, including representatives from African, Indian and Coloured groups. Class has become relatively independent of race (Ramphela, 1999; Jansen, 2004).

\section{Xenophobia in South Africa}

Over the past two decades there has been a notable increase in migration from the Southern African Developing Communities (SADC) region primarily due to the political and legal demise of apartheid in South Africa and the integration of South Africa into the global economy (Pendleton, 2008; Crush, 2008), Evident alongside this, South Africa has witnessed a rise in intolerance and animosity towards immigrants (Harris, 2002; Landau et. al; 2005; Reitzes, 2009). Foreigners are seen as a threat to the social and fiscal stability of South Africa (McDonald, 1998:1; McDonald et.al, 2000). They are seen as potential profiteers of South African resources and are represented as a physical disease that literally threatens the body politic with contamination (Perberdy, 1999: 296).

The state sees immigrants as a threat to the nation and the post-1994 nation building process. It conceptualizes most immigrants as Africans and Africans as potentially the most dangerous of all 'aliens'.

Why is this? It is important to understand the history of immigration in South Africa. During the apartheid era black immigrants were not allowed into South Africa, but white immigrants were granted access to the country. In the post-apartheid period, both white and black immigrants are allowed but the ethos of reception to black immigrants has largely been an unwelcoming one. Black immigrants have received legal access but not social acceptance. This could be attributed to the fact that the immigration of blacks into South Africa is a relatively new phenomenon, poses the unfamiliar and are in the face (direct and daily contact) of their black South African counterparts. White immigration to South Africa is an ongoing phenonmenon that happened even during the apartheid era and they are relatively distanced from black South Africans.

A review of the voluminous literature reveals distinct characteristics of xenophobia namely, 'an intense dislike or fear of strangers or people from other countries' (Crowther, 1995:1385; Plaut, 1999:1); 'deep dislike of foreigners or things foreign, which consist of various unexamined prejudices rather than considered and consistent views (De la Hunt, 1996:22); 'a 
fundamental fear of difference that can result in cultural shock' (Kleg,1993:8) a 'psychological state of hostility or fear towards outsiders' (Reynolds \& Vine, 1987:28) and a social condition and requires social explanation as it is a combination of intense dislike, fear for losing social, cultural or political control and the idea that 'the other' takes away opportunities entitled only to the hosting group (Tshitereke, 1999:1).

Several theses have been proposed to explain what is construed as xenophobia in South Africa namely, scapegoat theory (Morris, 1998; Tshitereke, 1999): a loathing and hatred for foreign nationals who are blamed for social ills such as crime, unemployment and the spread of diseases; relative deprivation theory (Tshitereke, 1999; Pillay, 2008): dissatisfaction and frustration with the slow pace of change and inadequacies in redressing the imbalances of the apartheid past force the deprived masses to turn against foreigners; isolation theory (Morris, 1998): apartheid insulated South African citizens from nationalities beyond Southern Africa and foreigners represent the unknown to South Africans; biocultural theory (Harris, 2002): locates xenophobia at the level of visible difference, or otherness that is in terms of physical biological factors and cultural differences exhibited by African foreigners in the country. And South African nationalism theory (Neocosmos, 2008:6) that advocates for a rural/urban binary explanation. Apartheid ruralised and devalued black lives while urbanising and valuing whiteness. This binary has shifted to the African/South African polarities whereby African is seen as rural and backward and South African as urban and modern and lends to the belief in 'citizenship as autochthony'.

\section{Theoretical Moorings}

Two theoretical underpinnings are used to frame the argument of this paper namely, social identity theory and social dominance theory. Social identity is a person's sense of who they are based on their group membership(s) (McLeod, 2008). Social identity theory focuses on 'the group in the individual' (Hogg \& Abrams, 1988:3) and assumes that one part of the selfconcept is defined by our belonging to social groups (Tajfel \& Turner, 1986). In order to increase our self-image we enhance the status of the group to which we belong (in-group) and discriminate and hold prejudiced views of the group we do not belong to (out-group). We divide the world into "them" and "us" based through a process of social categorization. Three mental processes are involved in evaluating others as "us" or "them" namely, social categorization, we categorize people (including ourselves) in order to understand the social environment; social identification, we adopt the identity of the group to which we have 
categorized ourselves and social comparison, we then tend to compare that group with other groups (McLeod, 2008). In order to maintain our self-esteem our group needs to compare favorably with other groups.

Social Dominance Theory is a theory of intergroup relations that focuses on the maintenance and stability of group-based social hierarchies (Sidanius \& Pratto, 1999). It focuses on both individual and structural factors that contribute to various forms of group-based oppression. Group-based inequalities are maintained through three primary intergroup behaviors; institutional discrimination aggregated individual discrimination, and behavioral asymmetry (Pratto et. al, 2006). Social dominance theory is characterised by hierarchy-enhancing and hierarchy-attenuating legitimizing myths (Pratto \& Steward, 2011). Hierarchy-enhancing ideologies such as racism and nationalism, contribute to greater levels of group-based inequality. Hierarchy-attenuating ideologies such as socialism and feminism, contribute to greater levels of group-based equality. The social dominance orientation and the individual's desire for unequal group relations dictates which of these legitimizing myths are endorsed and implemented.

\section{Research Strategy}

Meta-theoretically we were drawn to the tenets that govern social constructivism as our worldview. Methodologically the lens we utilised identifies our view as qualitative inquirers. The research design was qualitative in nature and the narrative method and case study approach was used. We employed narrative inquiry as it is a particularly useful method for this study. Narratives focus on the way in which individuals present accounts of themselves and their experiences (Burke, 2005). We thus, viewed narratives as a vehicle in which the research participants could express how they see themselves, whilst also shaping the image that they have of others (Clouston, 2003). We believe that utilising narrative interviews assisted the participants in this study to reflect back on past experiences and events and, by telling their stories, they may have gained additional knowledge both about themselves and others (Smith, 2000).

The cases for the study were defined by schools with Black immigrant students. We purposefully selected three schools from diverse socio-cultural settings for maximum variation (Glesne, 2006) that were located in the Gauteng province of South Africa; 
a former model $\mathrm{C}^{3}$ school, a former Indian ${ }^{4}$ school and an inner city ${ }^{5}$ school. The former Model C school comprised of students from all racial groups (White, Indian, Coloured and African and a few black immigrant students). Although some of these schools still maintained a 50\% white and 50\% black (Indian, Coloured and African) ratio. The former Indian school did not have any white students. At this school the majority of students were African with a sprinkling of Indian, Coloured and black immigrant students). The inner city school comprised mainly of African and Black immigrant students.

Data gathering techniques included a mix of semi-structured interviews, observations, field notes and researcher journals. Semi- structured interviews were conducted with a purposive sample of 15 [black] immigrant students across grades 8 to10. A total of 45 immigrant students were interviewed in 2011 over a period of six months. Semi-structured interviews were also conducted with principals, School Management Teams, School Governing Bodies selected teachers and parents. Observations of classroom practice, activities and associations during the break sessions, assemblies and other activities of the school including after school activities were captured. Data was analysed utilising content analysis (Mayring, 2000; Sandelowski, 2000). This paper reports on the data of Black African immigrant students. We relied both on previous analysis as well as revisited the data with a different lens. The lens is more discursive to identify the words used in order to describe what immigrant students are saying about how South African students treat them and what are they saying about South African students.

\section{Findings}

What are immigrants saying about how South African students treat them?

According to immigrant students, South African students treated them in a very negative way. The treatment of immigrant students could be clustered into four broad themes namely, categorisations and prototypes, practiced stereotypes; academic and social exclusion and work ethic.

\footnotetext{
${ }^{3}$ Model C school: A government attempt to cut state costs by shifting some of the financing and control of White schools to parents, during the apartheid era.

${ }^{4}$ Former Indian school: A school that formerly exclusively catered only to Indian students during the apartheid era.

${ }^{5}$ Inner city school: a school that mushroomed out of the need to cater to students who live in the inner city. The usually older, central part of a city, especially when characterized by crowded neighbourhoods in which lowincome, often groups predominate.
} 
Categorisations and Prototypes. Categorisation of immigrant students played out in three different ways. First, they were plugged into existing or new racial categories by South African students. Second, they were categorised according to 'shades of blackness'. And third, surnames of black immigrants were used as a means of categorisation. Immigrant students that shared similar phenotypical features as Africans in South Africa were labelled as "Makwerekwere".

They tell me to go back to where I came from ...I am a foreigner, a makwerekwere or something like that. I hate that word (Helen, Mozambique).

Immigrant students were categorised according to the 'blackness' of their skin pigmentation. Students who come from Congo, Zambia, Somalia, Malawi are naturally darker skinned than South African students.

They say you are black, like you are black more than other learners; you must be Congolese or maybe you from Somalia (Charles, Malawi).

Many immigrant students had unusual surnames that immediately served as an identity indicator. For example, Chizema, Uwitonge, Eguale, Lutumba, are uncommon surnames in the South African context.

Sometimes when the teacher takes roll call in the mornings and calls out our names, we can hear some students whisper 'makwerekwere' and sometimes they snicker and make fun of our surnames (Ogina, Kenya).

Practiced Stereotypes. Black South African students categorised black [African] immigrant students according to perceptions of their country of origin and sentiments expressed by fellow South Africans about immigrants from particular countries. Nigerians were categorised as thieves, womanisers, drug lords, and people who were unhygienic.

These Nigerians are all criminals! When they are not busy trafficking drugs, they are taking over our jobs, our houses and, worse, our women...they stink, they dirty and they are the ones that steal (Mpumi, South Africa).

Zimbabweans were ostracised because of the perception that they came from a povertystricken country that lacked resources and a country that would seem to be 'uncivilised' and 'backward' in some ways:

Before the exam we were in the hall and my friend and I were playing the piano in the hall, this South African guy comes in and he says 'are there pianos in your country? I thought like, what do you think we are in our country (Maria, Zimbabwe)?

\footnotetext{
${ }^{6}$ Makwerekwere: Derogratory term used by Black South Africans to describe other Africans.
} 
Academic and social exclusion. Academic and social exclusion manifested through language and group formations. Language played a pivotal role in terms of academic and social exclusion both inside and outside of the classroom.

Language is an issue. It marks you as an immigrant. For instance, when people speak in Zulu, I don't understand and I'm quite assertive and I tell them excuse me I'm here, please speak English let's all understand. They continue speaking in $\mathrm{Zulu}^{7}$ and then they say I am a makwerekwere and should go back to my country, this is the land of the Zulus (Kevin, Zimbabwe).

Black Anglophone [African] immigrant students found that they were discriminated against in terms of a lack of proficiency in indigenous African languages.

Yes, sometimes. Like when they speak their local South African languages, I try to join them but it's just hard and difficult. So you feel you're excluded, like you don't belong (Elufisan, Nigeria).

Black francophone [African] immigrant students were doubly disadvantaged as they entered the country lacking proficiency in both English and the indigenous African languages. These students were further disadvantaged as were the Anglophone students, when the teacher codeswitched during teaching in order to ensure that the local black students fully understood what was being taught.

I feel excluded, like an outsider. It forces me to learn Sotho. The South African learners and teachers talk Sotho most of the time. They like start speaking English and then, they go into Sotho ${ }^{8}$, like especially if one of the students asks a question, then they reply in Sotho and then the rest of the lesson continues in Sotho (Packo, Zambia).

Furthermore, code-switching was used by black South African students during breaks to entrench social exclusion. Many black South African students utilised the power of the indigenous languages as an exclusionary mechanism to exclude immigrant students from their social networks. During breaks one could witness pockets of ethnic groups intensely engaged in casual conversations through the use of indigenous languages.

They don't speak English when we in a group. I have to tell them English, English please and then they get all nasty and say you don't belong here (Jedidah, Zambia).

A tributary attached to the issue of language was that of accent. Accent was a clear indicator of immigrant status and contributed to academic and social exclusion.

\footnotetext{
${ }^{7}$ IsiZulu: one of the 11 official languages of South Africa.

${ }^{8}$ Sotho: one of the 11 official languages of South Africa.
} 
They call me a foreigner because of my accent. They like make jokes about the way I talk (Brenda, Nigeria).

The formation of groups inside and outside the classroom depicted another form of academic and social exclusion. During academic activities inside the classroom there seemed to be a tendency for South African students to exclude immigrant students from their group formations.

When the learners choose groups, most of the time, I don't have a group. (Andrew, Ghana).

Outside of the classroom, immigrant students found solidarity with other immigrant students as South African students utilised their indigenous languages and overtly excluded immigrant students from social networking.

Work Ethic. Although immigrant students in this study did not represent a homogenous group, that is, they came to South Africa from different countries and for different reasons, a common factor among them was their high level of commitment to their studies and their desire to perform well. They have a strong intrinsic drive and will to succeed,

What makes me willing and enthusiastic to come to school is just you know, that in life I want to be someone. (Annuarite, DRC).

Most immigrant students seem to be driven by the philosophy that if they keep quiet, keep to themselves and do their work they will be fine.

Basically I came to school to do my work and get good results. I don't care about making friends or whatever at school (Alice, Rwanda).

This was in stark contrast to the 'culture of entitlement' insolence and indiscipline of South African students as evident from the comments made by immigrant students, teachers and principals. Consequently, tension arose between immigrant and South African students. Immigrant students were serious about their education and wanted to work and in so doing exposed South African students' lack of value for education and their lack of moral integrity.

Sometime they say "why do you always do your homework? You are the ones that always getting us into doing homework. Because the whole class didn't do their homework, the teacher would think she forgot to give us homework and then they just lie and eish...it's frustrating you know (Jafta, Zambia). 


\section{What are immigrant students saying about South African students?}

Statements immigrant students make about South African students seem to fall into two broad categories namely, lack of value for moral integrity and lack of value for education

Lack of value for moral integrity. A central thread running through the narrative of immigrant students was that of the moral degeneration of black South African students. South African students seemed to lack a sound guiding value system as evident from their immoral and unethical conduct. They seemed to attach very little value to moral integrity as evident from statements made by immigrant students about their lack of moral norms, verbal vulgar abuse, theft, fighting and dating. Observations, comments and perceptions of these immigrant students seemed to strike the very chords of the moral fibre of South African society. Immigrant students seemed to suggest that there is something seriously amiss in our society.I love my culture because they have moral roles. Like kids here, some of them they go over, they do all these things kids their age are not supposed to do. But because of where I come from and my culture, I know my rights, I have respect. I know I am not supposed to do this until I'm of a certain age. (Unapa - Zimbabwe).

In my culture we are not allowed to wear trousers or to have a boyfriend when you're still at school; you can have a boyfriend when you're matured enough like 20 or 21. But here it's different because they [South Africans] wear clothes that really make them look like 'loose', like they have no morals and do totally different things...like drinking and smoking, drugs (Vanessa-Congo).

It's what they do. I didn't know that until when I came here... ' $F$ you', that's strange language. I heard many children saying this on my very first day at this school. I asked a friend that I had just met, what does it mean? [What impact did it have on you once you understood what it meant?] "It's not language I would like to use on anybody" (Andrew, Ghana).

Like me, I don't date, not at all...so a friend of mine can just tell me. Oh no, dating is fun and you must go. But I know it is wrong at this age (Annika Angola).

Lack of value for education. Coupled to the moral degeneration of South African students was their lack of value for education. Evidence of this was apparent in the behaviour of South African students. Immigrant students found South African students lazy, disrespectful and ill-disciplined. South African students seemed to 
project a culture of entitlement; they did not seem to understand the value of education and were constantly testing boundaries.

You know almost half of the period is used just to educate them [South African students] about their behaviour. Instead of teaching them the lesson the teachers now diverts to teaching them morals and discipline, and so it's always difficult for us (Charles, Nigeria).

There is more discipline back home [country of origin], it's more difficult to misbehave. Here sometimes the learners will talk back to the teacher... eish they don't respect their teachers (Mbeng, Cameroon).

It seems that many black South African students had adopted a culture of entitlement about education. That it is the duty of the government to give them an education. This 'culture of entitlement' seems to have filtered into the South African schooling system.

It has to do with "it's our country" attitude that they have. The local learners have a great sense of entitlement and at some stage abuse it (Andrew, Ghana).

Many immigrant students also expressed concern about the lackadaisical attitude of black South African students,

They don't even care about work and it actually worries me. South Africans don't seem to know where they are going. You can just see that they're not serious about education, they're not focussed (Vena, Zimbabwe).

Coupled to this lackadaisical attitude was their attitude towards any form of authority.

South African children like to test the boundaries; they spend more time doing this then actually concentrating on their studies (Mr Ismail, Principal).

\section{Discussion and analysis of findings}

What are immigrant students saying about how South African students treat them?

The three mental processes of social identity theory namely, social categorization, social identification and social comparison were clearly evident in the treatment of immigrant students by South African students. In order to understand the social context, South African students were quick to classify immigrant students into the social category of "makwerekwere”, utilising visible markers such as 'shades of blackness', surnames, language and accent. Furthermore, they defined their behaviour towards immigrant students by reference to the norms of groups to which they belonged. Social comparison was also apparent in the manner in which South African students compared themselves with immigrant students as evident from their practiced stereotypes. In order to maintain the selfesteem of the South African groups they needed to compare favorably with other groups. 
Hence comments such as "Nigerians are all criminals!'; "Nigerians...stink, they dirty and they are the ones that steal"; "Is there pianos in your country?" and "Are there swimming pools in Zimbabwe?". McLoed (2008) argues that this is crucial to understanding prejudice, because as soon as two groups identify themselves as rivals competition ensues for the members to maintain their self-esteem. Competition and hostility between groups is thus not only a matter of competing for resources like jobs, but more importantly it becomes an issue of competing identities.

In an attempt to maintain the stability of group-based social hierarchies, South African students quickly made a distinction between 'them' and 'us' as clearly evident in their attempts at academic and social exclusion of immigrant students. The three primary intergroup behaviors that maintain group-based inequalities namely, institutional discrimination aggregated individual discrimination, and behavioral asymmetry played out in various and nuanced ways. Institutional discrimination was evident in the way teachers codeswitched from teaching through the medium of English to teaching through the medium of one of the indigenous languages. Aggregated individual discrimination and behavioral asymmetry was clearly apparent in the manner in which immigrant students were treated by South African students. Coming from a legacy of apartheid, the social dominance orientation and the individual's desire for unequal group relations witnessed many South African students adopt hierarchy-enhancing ideologies such as racism and xenophobia to contribute to greater levels of group-based inequality.

\section{What are immigrant students saying about South African students?}

Let us look at the image created by immigrant students of South African students. This image fits apartheid stereotypes and probably some of it fits continued racism. Interestingly, immigrant students are not talking about whites; they are talking about Black South Africans. Where do they get this from? In one way they get it from their own value system. They all come from countries that have been colonised by Europeans and they might have been pictured by whites in these very same terms as they now picture Black South Africans.

\section{Racism and xenophobia}

In this study, the four pronged theory of xenophobia was clearly evident in the reactions of South African students to immigrant students. The scapegoat theory (Morris, 1998; Tshitereke, 1999) was apparent in South African students loathing and hatred for immigrant students. The deprivation theory (Tshitereke, 1999; Pillay, 2008) could be seen in South 
African students' dissatisfaction and frustration with the slow pace of change and inadequacies in redressing the imbalances of the apartheid past. A relatively high percentage of immigrant students happened to be amongst the poorest schools in South Africa. The injustice of this situation is that it is again, not the high sea schools with abundant facilities but the schools that are already suffering which become the playground for dealing with political and economic problems on a daily basis. The isolation theory (Morris, 1998) was evident in comments such as "Is there pianos in your country?" and "Are there swimming pools in Zimbabwe?" These comments are clearly indicative of the insulation of South African students from nationalities beyond Southern Africa and that foreigners represent the unknown to South Africans. And finally, the biocultural theory (Harris, 2002) which locates xenophobia at the level of visible difference, or otherness, as evident from the discriminatory practices of South African students namely, shades of darkness, language and accent.

An analysis of the findings of this study seem to suggest that the forms of exclusion that immigrant children report on relate to xenophobia and racism and that statements that immigrant students make about South African students relate to racism and a breakdown in the moral fibre of South African society. Many Black immigrants saw South Africa as a site of contamination and shame in terms of social norms and morality.

The image of South African students that is reflected in the 'inversed social mirror' ${ }^{9}$ is troublesome in its negativity. The picture that emerges depicts a person lacking in humane character, cultural mores and sound moral behaviour. Furthermore, the picture depicts South African students as judgemental and confrontational with a strong sense of territorialism and nationalism. Ironically, many of these students hailed from the 'born free' generation ${ }^{10}$. Yet, they had somehow managed to imbibe the atrocious conduct of the apartheid era. Why is this? South African students are left alone on how to deal with the history of the apartheid which is still very much on the shoulders of their parents and their frame of learning. The reaction of black South African students to immigrant students can be partly ascribed to the sharing of limited resources, but more importantly it is the fact that neither black South

\footnotetext{
${ }^{9}$ Inversed social mirror: involves learning about your own society through the eyes of others. It attempts to explore how immigrant students look at the host society.

${ }^{10}$ Born-free generation: Most of the South African students in this study were born in the year that South Africa attained democracy.
} 
African students nor their parents had the opportunity to find balance or the time to heal. And rather than healing in a protected space they are being thrown into an international competitive education system. Some students will be equipped to do that because they are on solid ground but if you are historically disadvantaged you are not on solid ground to meet this. In South Africa, international competition is not an abstract policy; it enters the school through immigrant students.

\section{Conclusion}

How does this injustice influence the education of both immigrant and South African students? Racism and xenophobia in all its horrific forms is transmitted across generations and is manifested as we have seen in individual behaviours, institutional norms and practices and cultural values and patterns. As such, it disrupts not only the mental health but also the psychological functioning of both victims and perpetrators of racial and xenophobic injustices.

Instead of focusing on their education these students are entrapped by the larger societal functioning of an ethnicised bureaucracy and national community. Perhaps it is time for stakeholders in education to take a stand and to actively work towards educating students about racism and xenophobia in an attempt to eradicate it and to promote social cohesion and harmony. A concerted effort should be made by both parents and educators to teach students to value human dignity and to view each other as cosmopolitan citizens of the world, in order to break the perpetuation of this vicious cycle of racism and xenophobia. However, if we agree that schools are a microcosm of society then the experiences of immigrant children are reflections of the ills in society at large. Perhaps we should begin re-educating adults.

\section{References}

Crowther, J., 1995. Oxford Advanced Learners Dictionary of Current English. International New Students. Fifth ed. $5^{\text {th }}$ edition. Oxford University Press, London,

Crush, J., 2008. South Africa: policy in the Face of Xenophobia. [online] Southern African Migration Project (SAMP). Migration Information Source. Available from: http://www.migrationinformation.rg/USfocus/display.cfm?ID=689. [Accessed 19 July 2011]. 
de la Hunt, 2002. Refugee migration to South Africa. Internet source: accessed 3 March 2009. www. alertnet.org/the facts/reliefresources/231016?

Essed, P., 2002. Everyday racism. In: Essed, P., \& Goldberg, D., (Eds.), Race Critical Theories. Oxford: Blackwell Publishers, pp. 176-194.

Gilroy, P. 1998. 'Race ends here.' Ethnic and Racial Studies. 21 (5), 838-847.

Gilroy, P., 2000. Against Race: Imaging Political Culture Beyond the Colour Line. Harvard University Press, Massachusetts.

Glesne, C., 2006. Becoming Qualitative Researchers: An Introduction, Pearson Publishers Inc., New York.

Hall, S., 1992. 'New Ethnicities': Race, Culture and Difference. In: Rattansi, A., \& Donald, J., (Eds.), Muslims in Western Europe. Edinburgh University Press, Edinburgh, 278-292.

Harris, B., 2002. Xenophobia: a new pathology for a new South Africa? In: Hook, D., \& Eagel, G., (Eds.), Psychopathology and Social Prejudice, University of Cape Town Press, Cape Town, pp.169-184. Available from: http://www.csvr.org.za/wits/papers/paphari.html [Accessed 22 July 2011].

Hassim, S., Kupe, T., \& Worby, E., 2008. Go home or die here. Violence, xenophobia and the reinvention of difference in South Africa, Wits University Press, Johannesburg.

Hogg, M. A., \& Abrams, D., 1988. Social Identifications: A Social Psychology of Intergroup Relations and Group Processes, Routledge, London.

Jansen, J., 2004. Race, education and democracy after ten years-how far have we come? Prepared for the Institute for Democracy in South Africa (IDASA), Lessons from the Field: A Decade of Democracy in South Africa.

Kleg, P., 1993. Hate, Prejudice and Racism, State University of New York Press, Albany.

Krochmal, R., 2001. The current refugee situation in South Africa: Cause for concern. Internet Source accessed 4 March 2003. www.alertnet.org/the facts/reliefresources/231016?

Landau, L.B., Ramkathan-Keogh, K., \& Singh, G., 2005. Xenophobia in South Africa and Problems Related to It. Forced Migration Working Paper Series 13, Wits University Press, Johannesburg.

Mayring, P., 2000. Qualitative Content Analysis, Forum for Qualitative Research: Qualitative Social Research [On-line Journal], 1(2). Available at: http://qualitativeresearch.net/fqs/fqs-e/2-00inhalt-e.htm [Accessed 26 : 03: 2010]

McLeod, S. A., 2008. Social Identity Theory. Retrieved from http://www.simplypsychology.org/social-identity-theory.html Miles, R., 1982. Racism and Migrant Labour: A Critical Text, Routledge, London. 
Morris, A., 1998. 'Our fellow Africans make our lives hell': the lives of Congolese and Nigerians living in Johannesburg, Ethnic and Racial Studies, 21 (6), 1116-1136.

Neocosmos, M., 2008. The Politics of Fear and the Fear of Politics [online].

Available from: http://www.pa,mbazuka.org/en/category/features/48712.

[ Accessed 19 July 2011].

Neocosmos, M., 2006. From Foreign Natives to Native Foreigners, Explaining Xenophobia in Post-apartheid South Africa, Citizenship and Nationalism, Identity and Politics. CODESRIA Monograph Series, Dakar, Senegal.

Peberdy, S., 1999. Selecting immigrants: Nationalism and national identity in South

Africa's immigration policies, 1910-1998, Unpublished doctoral theory, Queens University, Canada.

Peberdy, S., \& Crush, J., 1998. Trading places: Cross-border traders and the South African informal sector, SAMP Migration Series No.6, Kingston, Cape Town:

Pendleton, W., 2008 Migration and Xenophobia in Southern Africa In: Hinzen, H., (Ed.), Migration and Integration. Number 70 [online] Available from: http://www.iizdvv.de/indez.php?article_id=726\&clang=1 [Accessed 19 July 2011].

Pillay, D., 2008. Relative deprivation, social instability and cultures of entitlement. In: Hassim, S., Kupe, T., \& Worby, E., 2008. Go Home or Die Here. Violence, Xenophobia and the Reinvention of Difference in South Africa, Wits University Press, Johannesburg, pp. 9698.

Plaut, W. G., 1999. Urban alliance on race relations. Current, 7(1).

Pratto, F., Sidanius, J., \& Levin, S., 2006. Social dominance theory and the dynamics of intergroup relations: Taking stock and looking forward. European Review of Social Psychology. 17, 271-320.

Pratto, F., \& Steward, A.L., 2012. Social Dominance Theory. In: Daniel, J., Christie, L., (Eds.), The Encyclopaedia of peace psychology. Blackwell Publishing Ltd.

Ramphele, M., 1999. Immigration and education: International students at South African universities and technikons. SAMP Migration Policy Series No.12, Cape Town: Kingston.

Reitzes, M., 2009. Xenophobic triggers situated in the history and legal provisions of domestic and international migration policies in South Africa. In: Richards, r., (Ed.), Synopsis, (10)3, 9-14. Policy Studies Bulletin of Centre for Policy Studies.

Reynolds, V., \& Vine, I., 1987. The Socio-biology of Ethnocentrisms: Evolutionary

Dimensions of Xenophobia, Discrimination, Racism and Nationalism, Croom Helm, London. 
Sandelowski, M., 2000. Focus on Research Methods. Whatever happened to qualitative description? Research in Nursing and Health, 23, 334-340.

Sidanius, J., \& Pratto, F., 1999. Social Dominance: An Intergroup Theory of Social Hierarchy and Oppression, Cambridge University Press.

Tajfel, H., \& Turner, J. C., 1986. The social identity theory of intergroup behaviour. In: Worchel, S., \& Austin, W.G (Eds.), Psychology of Intergroup Relations, Nelson-Hall, Chicago, IL, pp. 7-24.

Tshitereke, C., 1999. Xenophobia and relative deprivation, Crossings, 3(2), 4-5.

Southern African Migration Project, Idasa, Cape Town and Queen's University, Kingston.

Vandeyar, S., 2010. Educational and Socio-cultural experiences of immigrant students in South African schools, Education Inquiry, 1 (4), 347-365.

Vandeyar, S., \& Vandeyar, T., 2011. Articulating cultures: Sociocultural experiences of Black female immigrant students in South African schools, International Journal of Gender \& Behaviour, 9 (2), 4161-4188.

Vandeyar, S., 2011. Immigrant students' shifting identifications in South African schools, International Journal of Educational Development, 32, 232-240.

Vandeyar, S., \& Vandeyar, T., 2012. Renegotiating identities and reconciling cultural ambiguities: Socio-cultural experiences of Indian immigrant students in South African schools, International Journal of Social Sciences, 33(2), 155-167.

Vandeyar, S., 2013. Youthscapes: the politics of belonging for "Makwerekwere" youth in South African schools. International Journal of Citizenship Studies, 17 (3/4), 447-463.

Vandeyar, S., 2006. Teacher-Student interactions in Desegregated Classrooms in South Africa. International Journal of Educational Development, 26 (4), 362-393.

Wallace, C., 1999. "Xenophobia in Transition: Austria and Eastern Europe Compared." (Research Report). Vienna: Institute for Advanced Studies.

\section{Author biographies}

Prof. Saloshna Vandeyar is an NRF C2-rated scientist and the winner of the international Comparative International Education Society (CIES) Best Article 2011-2012 Award and the American Education Research Association (AERA) Mid-Career (Teaching and Teacher Education) Award 2011. She is the recipient of the prestigious international BMW Group Intercultural Award in the category: Theory (2006). Her work has also received national recognition: she was a finalist in the 2013-2014 NSTF individual 
over a lifetime award and received the Education Association of South Africa (EASA) Research medal in 2011. She received the National Science and Technology Forum (NSTF) Award in 2007 (Senior Black Researcher over the last 5 to 10 years) and was a finalist in the Education category of the Shoprite Checkers/SABC 2 Woman of the Year Award in 2006. She also received the Education Innovation Laureate award (2012); the Exceptional Young Researcher Award from the University of Pretoria and two Community awards. She was nominated for the Social Justice in Education Award (AERA) in 2009. Her scholarly book Diversity High: Class, Color, Culture and Character was nominated for the Outstanding Book Award (AERA) in 2009 and one of her papers, pub-lished in an international journal, was nominated for the Joyce Cain Award (2009). These scholarly awards recognise her considerable contributions to the field of diversity education. Her specialist areas encompass identities, race and social justice education, teacher professionalism and assessment practices. She is an active member of AERA, CIES and EASA and serves on a number of editorial boards of international and national journals. She has published widely in both internationally and nationally accredited journals and is the author of a number of scholarly books and chapters. She has numerous international networks and has presented many invited keynote addresses. She is particularly interested in the implications of teacher and student iden-tities in constructing classrooms inclusive of racial, linguistic and ethnic identities and in promoting intercul-tural and social justice education.

Dr Thirusellvan Vandeyar has been a full-time lecturer in the Department of Science, Mathematics and Technology Education in the Faculty of Education since 2006. His prior teaching experience includes being a head of department for mathematics, deputy principal and principal at schools and a lecturer at a teacher training college. During his extensive teaching career, he obtained a BA degree and a Diploma in Datamatrix. Currently he holds a Master's and $\mathrm{PhD}$ degree in Computer Integrated Education. His main research interests include e-learning, teacher professionalism, education policy implementation and best practices in the use of ICT in teaching and learning. His current research projects focus on Exceptional Patterns of ICT integration in teaching and learning and ICT for Education, Development and Social Justice. 